species of the genus Eucalyptus, which have shown remarkable growth, especially in youth. Série Technique No. 69: Contribution à l'Étude de l'Eucalyptus au Rwanda et au Burundi, by M. Reynders, is concerned with trials of some of these species at an elevation of nearly $1,500 \mathrm{~m}$ in central Congo, where the annual rainfall is between $850-1,300 \mathrm{~mm}$, with a dry season of three months and a mean annual temperature of $18^{\circ} \mathrm{C}$ and where the soils are somewhat variable (Publications de l'Institut National pour l'Étude Agronomique du Congo. Série Technique. Pp. vii +242 . Bruxelles: Institut National pour l'Étude Agronomique du Congo, 1963. 125 Franes). The first part deals with the trials of 16 species of Eucalyptus on three different sites and the experiment was laid out on a randomized block design, giving 16 treatments and 5 replications, using 200 trees per plot. Planting was made in 1954 and the statistics included those of the first thinning, which took place at 5 years. The regression of volume on basal area was established and an analysis of variance completed. The results demonstrated the particular success in growth and volume production of $E$. botryoides. The author points out the difficulties of handling the field, work for such an experiment because of the large area required, and he suggests that it would have been better to reduce the number of species to perhaps 10 by some initial sorting trial. The second part is a comparison of the production from eucalypt plantations worked as coppice-with-standards, with the standards at various densities, and a simple coppice control. The results showed no significant difference between the treatments in total production. Therefore, the choice of treatment is largely dependent on the type of produce desired by the forest manager-a greater density of standards being kept if more of the larger-sized material is required. This publication is interesting not only for its account of the use of various species of Eucalyptus for high-elevation afforestation in tropical Africa but also for the statistical handling of the data. The findings are well illustrated by graphs.

\section{Society for Analytical Chemistry}

A MEETING on "Atomic Absorption Spectroscopy", arranged jointly by the Midlands Section and the Physical Methods Group of the Society for Analytical Chemistry, together with the East Midlands Section of the Royal Institute of Chemistry and the University of Leicester Chemical Society, will be held in the University of Leicester on February 25. A social meeting, also arranged by the Midlands Section of the Society, will be held in the University of Birmingham on February 28. It will include a short talk on wines and a film. A one-day symposium on "Thin Layer Chromatography", arranged by the Midlands Section and the Thin Layer Chromatography Panel of the Society in conjunction with the Birmingham and Midlands Section of the Royal Institute of Chemistry, will be held in the University of Birmingham on October 14, at which the plenary lecture will be delivered by Prof. Egon Stahl (University of Saarlandes). Further information on all three meetings can be obtained from the secretary of the Midlands Section of the Society for Analytical Chemistry, Mr. M. L. Richardson, c/o John and E. Sturge, Ltd., Lifford Lane, Kings Norton. Birmingham 30.

\section{University News:}

Birmingham

THE titles of reader have been conferred on the following: Dr. A. S. Jones (chemistry); Dr. J. E. B. Randles (chemistry); Dr. J. L. Jinks (honorary reader in genetics). The following appointments have been made: Lectureships, Miss Lorna Maclay (psychiatry). Research fellowships, Dr. O. C. Forbes (Senior Research Fellow), Dr. M. Hayward, Dr. J. Lines and Dr. P. O'Brien (medical biochemistry and pharmacology); Mr. W. E. G. Cooper (dental pathology).

\section{Essex}

The Plessey Company, Ltd., Ilford, has given $£ 50,000$ to the University of Essex Foundation Fund Appeal. The donation will contribute to the support of scientific research and research staff at the new University.

London

THE title of professor of spectroscopy has been conferred on Dr. W. R. S. Garton in respect of his post at the Imperial College of Science and Technology. The title of reader in pharmacology has been conferred on Dr. W. C. Bowman in respect of his post at the School of Pharmacy. The title of reader in chemical pathology has been conferred on Dr. I. MacIntyre in respect of his post at the Postgraduate Medical School of London.

\section{Announcements}

Dr. B. R. Nijhawan, director of the National Metallurgical Laboratory, Jamshedpur (India), has been nominated on the Board of Directors of the National Mineral Development Corporation of the Government of India.

AN international conference on "Lattice Defects in Quenched Metals" will be held at the Argonne National Laboratory during June 15-17. Further information can be obtained from R. M. J. Cotterill, Building 212, Argonne National Laboratory, Argonne, Illinois.

A symposium on "Molecular Structure and Spectro. scopy" will be held at the Ohio State University during June 15-19. Further information can be obtained from Prof. H. H. Nielsen, Molecular Spectroscopy Symposium, Department of Physics, Ohio State University, 174 West 18th Avenue, Columbus, Ohio.

The twentieth meeting of the Conférence Internationale des Grands Reseaux Electriques will be held in Paris during June 1-10. Problems under discussion will include the fields of generation, transformation and distribution of high-voltage electrical energy. Further information can be obtained from the British National Committee, C.I.G.R.E., c/o Electrical Research Association, Cleeve Road, Leatherhead, Surrey.

AN international symposium on "The Chemistry of Natural Products", organized by the Science Council of Japan under the auspices of the International Union of Pure and Applied Chemistry, will be held in Kyoto during April 12-18. Further information can be obtained from the Organizing Committee, International Symposium on the Chemistry of Natural Products, Science Council of Japan, Ueno Park, Tokyo.

THe anniversary meeting of the Chemical Society will be held in Birmingham during April 7-9. The programme will include the following symposia: synthetic and stereochemical aspects of organic chemistry; inorganic halogen chemistry; new methods of organic analysis; molecular structure and arrangement. The Robert Robinson Lecture will be delivered by R. B. Woodward (Harvard University). Further information can be obtained from the General Secretary, the Chemical Society, Burlington House, London, W.1.

Erratum. With reference to the communication entitled "Co-linearity of the Gene with the Polypeptide Chain", which appeared in Nature of January 4, p. 13, Dr. S. Brenner has written to the Editor stating that the work of Dr. Yanofsky et al. on the co-linearity of the gene and the protein of the tryptophan synthetase of $E$. coli was reported by Dr. Yanofsky at the 1963 Cold Spring Harbor Symposium of Quantitative Biology, and that reference should have been made to the following: Yan. ofsky, C., Cold Spring Harbor Symp. Quant. Biol., 28 (in the press); and in The Bacteria, 5, edit. by Gunsalus. I. C., and Stanier, R. Y. (Academic Press, New York. in the press). 